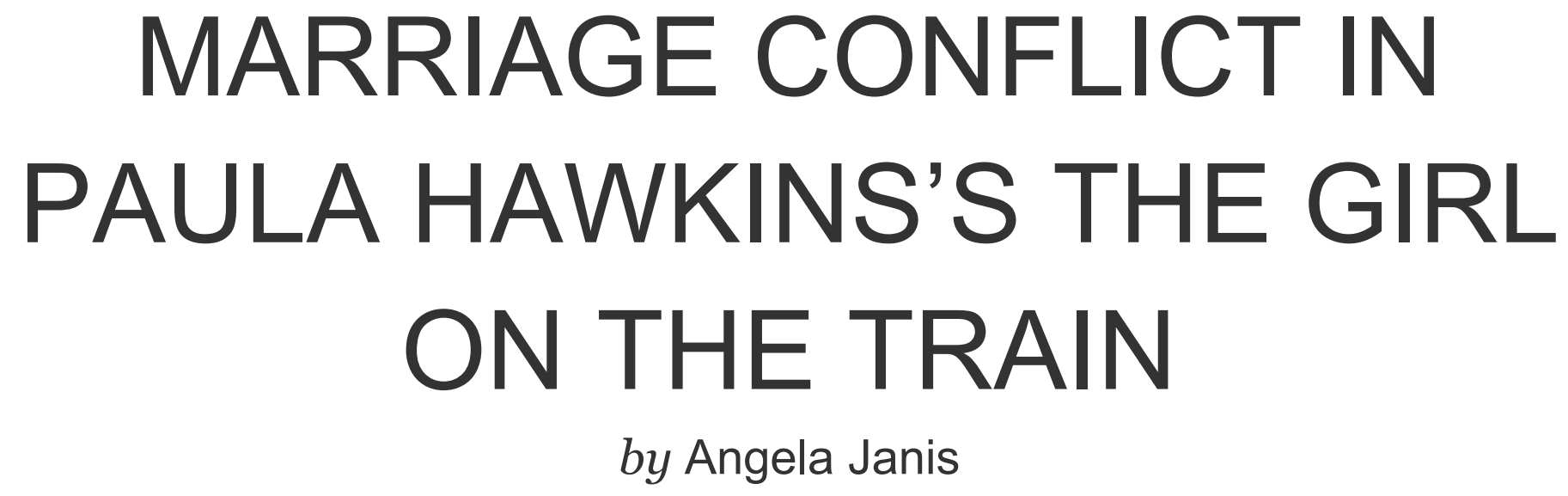

Submission date: 23-Jan-2021 01:58PM (UTC+0700)

Submission ID: 1492726446

File name: AP_ANGELIA_A._JANIS.docx (53.13K)

Word count: 6339

Character count: 30168 


\title{
MARRIAGE CONFLICT IN PAULA HAWKINS'S THE GIRL ON THE TRAIN
}

\author{
Angelie Aurelia Janis, Mister G. Maru, Delly Sabudu \\ Universitas Negeri Manado, Tondano, Indonesia \\ Angeliaaurelia25@gmail.com
}

Abstract: This research has 21 o purposes, firstly to reveal the Marriage Conflict and to find out the cause and effect in the Girl on the train by Paula Hawkins. The writers use qualitative research as the design in this study. The data are collected in t 20 form of words and is present in the form of quotes or descriptions. The main source in the novel itself is The girl on the Train by Paula Hawkins, and secondary sources are other related documents such as relevant books, dictionaries, internet browsing, other literary works. In analyzing the data, the writers use objective approach. In brief, this concentrates on the work itself without considering the outer part of the novel such as the social background of the novel. This approach leads the writers to analyse the work only focusing on the work itself, in which how the interrelationship of the elements of the novel have built and formed. The result shows that the conflict occurred th 20 irst marriage conflict, and the second marriage conflict caused by the character of the novel The Girl On The Train by Paula Hawkin's namely Tom. A selfish husband who is never satisfied, while the characters involve so that the conflict occurred is Rachel former Tom's wife who could not give a child to Tom, Anna cheates Tom and becomes Tom's wife and Megan Tom's second affair. The first marriage conflict occurred between Tom and Rachel because Tom had an affair with the reason Rachel could not provide child. The second marriage conflict occurred between Tom and Anna. Previously Anna was Tom's affair until she became his wife, Anna who disturbed other people's household relationships so that she brought fear to herself about Tom's ex-wife's existence. Tom, who triggered a conflict between his first marriage and his second marriage, brought destruction into his life and ended in death.

Keywords : Marriage Conflict, Husband And Wife, Divorce

\section{INTRO $_{13}$ UCTION}

Marriage is a legal relationship between a man and a woman to live together eternally, which is recognized by 27. State (Paul Scholten,1986;13) Marriage as a legal relationship between a man and a woman for a long time (Prof. Subekti, S.H, 2015; 35).

According to Law number 1 of 1974, marriage is an inner and outer bond between a man and a woman as husband and wife with the aim of forming a happy and eternal family (household) based on a
Godhead. If further examination of the above definition can be concluded the conclusion that the essence of the institution of marriage is as follows: A marriage in order to be vali $255 \mathrm{r}$ recognized by law. This can happen if the marriage takes place according to the provisions of the Act.

But what has happened now, marriages are not only carried out by the opposite sex, but also carried out by the same sex, and in some countries such marriage has been approved.

Similar marriages (also known as gay marriages) are mari 3 ges of couples of the same sex, through a civil or religious 
ceremony. The term marriage equality refers to political status, that is, marriages between same-sex couples and law recognizes diffrent-sex couples equally. The main supporters of same-sex marriages are human rights organizations and civil rights as well as the scientific and medical community, while the main opponents are religious groups. Some sect communities in the world support samesex marriage, although many religious groups oppose it. Opinion polls consistently sh $3 \mathrm{~N}$ a continuous increase in support of recognition of same-sex marriage in all developed democracies and some developing democracies.

Based on some definitions of marriage above, it can be the author concludes that marriage is a marriage ceremony binding ceremony, which is carried out by two people with the intention of formalizing ties marriage before the headman and registrar of marriage with the intention to obtain an authentic deed about the recording of marital events.

Marriage is considered as an important phase in the human life cycle. Just like fashion, marriage also has its own trends or fashions. As for the theories in marriage that apply in Indonesia, namely marriaga 26 according to civil law, marriage in the perspective of Islamic law, Marriage according to Law Number 1 of 1974, marriage according to customary law and the basics of marriage law.

Everyone wants happiness in marriage, but in reality not all people who get married get happiness. In the story in this novel at the first marriage there was no happiness because they could not have children, so Tom would prefer another woman. The second marriage has been equipped with the presence of a child as this has been very desired by Tom for a long time, but could not also bring happiness in this married life because of the nature of Tom does not get sexual satisfaction from his wife and he teased other w6men and had an affair.

Conflict is an expression of conflict between individuals with other individuals, groups with other groups for several 6 asons. In this view, disputes indicate differences between two or more individuals who are efpressed, remembered, and experienced. (Pace and Faules, 1994: 249)

Conflict is an interaction called communication between individuals with one another; undeniably it will cause conflict on different levels (Devito, 1995: 381).

A conflict can occur when a partner has different views, sometimes conflict can occur when people misunderstandi 18 and miscommunicate one another. A conflict that is not resolved may lead to arguments and resentment. It is normal to disagree with each other. Occasionally a conflict is a part of family life. However, continuously conflict can be stressful and damaging to relationship. There are 2 factors that cause marriage conflict in this novel, namely external factors in the first marriage is the presence of a teaser named Anna. Internal factors at the first marriage are occurred because of Tom's selfishness and lies to Rachel. External factors in the second marriage as well as the second marriage are a teaser named Megan. Internal factors in the second marriage are that there is no sexual satisfaction that causes infidelity.

This research is important to be raised so as to bring more awareness to the public to stay away from problems that will have a negative impact on marriage as taken in the story of the novel The Girl On The Train because of one's selfishness, so 
that infidelity occurs and triggers this marriage conflict to occur so that it ends on Divorce.

The writers and speaker may be able to learn more from the problems that cause conflict and talk more about marital relationships.

The Girl on the Train novel is an interesting novel obtained from The Unite State. Author Paula Hawkins says the reason for writing this novel is "I realize I would think that thi4e are many women who have edited." The Girl on The Train (2015) is a novel by the British Author PAULA HAWKINS. The novel debuted at NO.1 in the New Yor 14 Times, the bestselling Best Seller in 2015. In January 2016 he became the No.1 best seller again for two weeks.

In addition, This study also becomes one of the art of literary work because it is involved the element of litis ature as Wuntu (2015:100) said that "A literary work which has affective nature is a significant power to touch the deepest sense that can produce perfect consciousness as it successfully carries out its mission as a form generator of human consciousness". Maru also states "Since the ingredients of literature 19ure taken from daily life, it touches every human dilemma, conflict ad yearning unraveling the plot of a short story or decoding the dialogue of a play and is more than a mechanical exercise" (Maru 2009:5)

\section{METHODOLOGY}

\section{Resear(5) Design}

This research is classified as qualitative research since the data of 5 tained are in the form of words. "Qualitative research is descriptive. The data collected are in form of words or pictures rather than numbers. The writers result of the research contains from the data to illustrated and substantiate the presentation" ( Bogdan and Biklen 1992 : 28 ) In other words, the qualitative research uses data in the form of picture of words. They are presented descriptively. The data in this research are taken from primary source, in this case the novel itself and secondary sources.

\section{Data Collection \\ Primary source}

The primary source to the research is the work itself.

\section{Secondary source}

The secondary sources are taken from book such as literature books; research methodology and some data are explored from sites in the internet.

12

\section{Data Analysis}

Data analysis is the process of systematically searching and arranging the interview, transcript, fieldnotes, and other materials that you accumulate to increase your own understanding of them and to enable you to present what you have discovered to others, (Bogdan and Biklen1982;153)

In analyzing the data, the writers will use the objective approach. About the objective approach: "The objective orientation which on principle regards the work of art in isolation from all these external points of reference, analyzes it is a self-sufficient entity constituted by its parts in their internal relations, and sets out to judge it solely by criteria intrinsic to its own mode of being." (Abrams 1979;26)

It means that in understanding and analyzing the data, the writers should be focused on the work itself. So in the other words the writers use the novel to get the answer of the problem. The writers use 
objective approach because the writers want to find out the elements of the works in this case the conflict of the novel. The writers focus on conflict. Conflict is important element in plot, and plot an element in novel.

\section{ANALYSIS}

\section{Marriage in General}

Humans are always looking for other humans to live together. Living together is a normal fact for humans, and only humans who have abnormalities are able to isolate themselves from other people. It has become the nature of nature, two hu $24 \mathrm{n}$ beings with different gender genes, a woman and a man; there is a power to attract one another to live together. In this case the minds of the people who are intended or intended for intercourse between the two human beings before, when it can be done this intercourse can be an important motivating factor to live together before, either by looking for children of their own descendants as well only can breathe sheer lust. Furthermore, it is considered that living together has a very important effect in social life and the most important thing related to living together between these two human beings is simply to separate oneself from other members of the community and to discuss more about what happens to children, with those children they are separate families. In connection with the very important of living together, then the community needs rules about living together about the requirements for the inauguration, implementation, continuation and termination of the life together. And these regulations determine the rules of marriage, namely living together with men and women who meet the conditions included in the regulation. For this reason, the author draws thinks that marriage is a shared life that is taken from a biological standpoint and meets the requirements of certain regulations.

According to Law number 1 of 1974 , marriage is an inner and outer bond between a man and a woman as husband and wife with the aim of forming a happy and eternal family (household) based on Godhead. If further examination of the above definition can be concluded the conclusion that the essence of the institution of marriage is as follows: A marriage in order to be vali $25 \mathrm{r}$ recognized by law. This can happen if the marriage takes place according to the provisions of the Act.

But what has happened now, marriages are not only carried out by the opposite sex, but also carried out by the same sex, and in some countries such marriage has been approved. Similar marriages (also known as gay marriages) are marritiges of couples of the same sex, through a civil or religious ceremony. The term marriage equality refers to political status, that is, marriages between samesex couples and different-sex couples are 3 cognized equally by law. The main supporters of same-sex marriages are human rights organizations and civil rights as well as the scientific and medical community, while the main opponents are religious groups. Some sect communities in the world support same-sex marriage, although many religious groups oppose it. Opinion polls consistently show a 3ontinuous increase in support of recognition of same-sex marriage in all developed democracies and some developing democracies.

Based on some definitions of marri 31 above, it can be the author think that marriage is a marriage ceremony binding which is carried out by two people 
with the intention of formalizing this marriage before the headman and registrar of marriage with the intention to obtain an authentic dead about recording 17 marriage events. Marriage is considered as an important phase in the human life cycle. Just like fashion, marriage also has its own trend of fashion

\section{Marria 13 Conflict}

Marriage is a legal relationship between a man and a woman to live together eternally, which is recognized by the Stat6. ( Paul Sckolten,1986; 13 ) Conflict is an expression of conflict between individuals with other individuals, groups with other groups for several 6 asons. In this view, disputes indicate differences between two or more individuals who are e 6 pressed, remembered, and experienced. (Pace and Faules, 1994: 249). Conflict is an interaction called communication between individuals with one another; undeniably it will cause conflict on different levels (Devito, 1995: 381).

There are 3 types of conflict that occur in marriage, namely :

-Conflict type 1: Problems that can be resolved Examples of this type of conflict are practical matters such as the division of household duties or how to raise children without any other bigger problems.

-Conflict type 2: Perpetual problem. This is the type of conflict that is most often experienced by married couples. This problem usually occurs because of repeated personality differences. For example, one partner is used to being neat while the other tends to be messy.

-Conflict type 3: A recurring problem that is "stuck" (gridlock) This type of conflict is uncomfortable to discuss because husband and wife have different opinions. Usually this conflict is based on an issue that is bigger than it seems

\section{Solutions}

Solutions overcoming various types of conflicts are:

-Understanding the type of conflict that occurs with your partner

-Start evaluating conflict with your partner

-Managing the most appropriate conflicts to be resolved.

Every married couple will definitely meet a conflict; some even experience it in the near future from the first conflict to the next. Whether it's from mild type of conflict, even though it's hard. Understanding the type of conflict that usually occurs between our partners and us is very important for harmonious domestic relationships in the future. By understanding this type of conflict, we can determine the most appropriate way of conflict management.

Conflict that occurs in a marriage cannot be allowed to continue, there must be an effort to resolve conflicts that occur in order to impact negative results caused by the conflict can avoided. Conflict that is not resolved properly will have a negative impact on life marriage and also have a long-term impact for other family members. Hence the researchers look at that conflict resolution pattern marriage needs to be stu22 ed further. This research will discusses patterns of marital conflict resolution a 23 the factors that influence its formation patterns of marital conflict resolution in individuals.

The Girl on the train describes about a man who is involved with three women. Tom Watson is Rachel's ex- 
husband who divorced Rachel for not having children, so Tom had an affair with Anna and impregnated her and then married Anna and then had an affair with Megan. Anna, invited, Tom, always thinks that Rachel is the mastermind of everything that is wrong. Tom who has had a new family is involved with Megan. Seeing this literary phenomenon, the authors formulate rese $22 \mathrm{~h}$ related to conflict, Paula Hawkins; Girl on the train. It is hoped that the author will discuss the deeper understanding and revelation of the image of marriage conflict in the novel.

\section{Unable to have child}

The Girl On The Traintells of a confusing marriage that took place at the first marriage between Tom and Rachel. Tom and Rachel used to love each other but their marriage was broken because Rachel cfeld not give a child to Tom.

"I was still young, there was still plenty of time, but failure cloacked me like a mantle, it overhelmed me, dragged me under, and I gave up hope. At the time, I resented the fact that it was always een as my fault, that I was the one letting the side down. But as the speed with which the managed to impregnate Anna demonstrates, there was never any problem with Tom's virility. I was wrong to suggest that we should share the blame; it was all down to me." (Hawkin's ,117)

The quote above explains that Rachel is very bad with the situation that they always tried to have children. Rachel's life is still relative to having children. The topic of getting children has become a common topic that is often asked of 'Tom and Rachel.

"It didn't happen. No, doctor has been able to explain to me why I can't get pregnant. I'm young enough,fit enough, I wasn't drinking heavily when we were trying. My husband's sperm was active and plentiful. It just didn't happen . I didn't suffer the agony of miscarriage, I just didn't get pregnant. We did one around of IVF, which was all we could afford. It was, as everyone had warned us it would be, unpleasant and unsuccessful. Nobody warned me it would break us.But it did. Or rather, it broke me and then I broke us." ( Hawkin's , 116)

The quote above explains that there is no problem with Rachel's age and physical condition which is very difficult to get pregnant, as for a series of efforts and procedures and various therapies that they are trying to have a child but Rachel still cannot get pregnant. The situation is being experienced by the two of them is a difficult situation to accept at a marriage. This makes Tom bored, so Tom secretly teases a womarghamed Anna.

"I feel asleep last night thingking of you, I was dreaming about kissing your mouth, your breasts, the inside of your things. I woke this morning with my head full of you. Desperate to touch you. Don't Expect me to be sane, I can't be, not with you." (Hawkin's,111)

The above quote explains that Tom is a very selfish man because in a state of decline with his wife, he teases other women. The affair that occurred between Tom and Anna, several meetings took place, so this affair made Anna Pregnant and Rach 4 feel very down.

" I was still young, there was still plenty of time, but failure cloacked me like a mantle, it overwhelmed me, dragged me under, and I gave up hope. At the time, I resented the fact that it was always seen as my fault, that I was the one letting the side down. But as the speed with which he managed to impregnate Anna demonstrates,there was never any 
problem with Tom's virility. I was wrong to suggest that we should share the blame ; it was all down to me". (Hawkins, 117)

Tom impregnates his affair; his wife's deterioration of this incident made him become an alcoholic, and felt his life was no longer meaningful. With something like this, Tom divorces Rachel, and chooses Anna to marry him. Some time later Tom and Anna married and had a daughter named Evvie.

\section{Emotional and sexual disatifaction}

After the divorce took place at the first marriage, the second marriage began between Tom and Anna. This relationship starts from the affair who is now married. Tom left his ex-wife and chose Anna. New married life begins, complemented by a princess. There is a feeling of Tom's love for 2 nna.

"I open my eyes and
Evvie'ssmiling, too, and when I look up,Tom's standing at the foot of the bed, holding a tray. He's wearing my oral Kierly apron and nothing else. "Breakfast in bed, birthday girl," he says. He places the tray at the end of the bed and scoots round to kiss me. I open my present. I have a pretty seilver bracelet with onyx and inlay from Evvie,and a black silk teddy and matching knickers from Tom, and I can't stop smiling. He climbs back into bed and we lie with Evvie between us. She has her fingers curled tightly around his forefinger and I have hold of her perfect pink foot, and I feel as though fireworks are going off in my chest. It's impossible,this much love. “ (Hawkin's , 162-163).

The quote above is when Anna woke up early on her birthday and got a surprise from Tom. There was love illustrated at that time, the three of them gathered on the bed, Anna was very happy about this and thought it was impossible that Tom loved her but Tom did love Anna. Happiness in this marriage is intact, that is Tom's love for Anna, which is complemented by the fruit of their love, Evvie. But this integrity does not make Tom stay loyal to his wife. This happiness was marred by Tom's selfishness who tried to ten 1 t other women.

"I was still fat, exhauted, raw, off sex. But then I start to laugh,because this is just ridiculous, it can't be true. We were blissfully happy in September, in love with each other and with our new baby. There is no way he was sneaking around with her, no way in hell that he's been seeing her all this time. I would have known. It can't be true." ( Hawkin's , 393)

The above quote proves that Tom is teasing other women, because he no longer gets sexual satisfaction from his wife. At that time was the time of their daughter's presence; the happiness gained by the presence of a child does not keep Tom loyal to his wife. As the responsibility of a woman that is having to take care of her husband and children, his wife is busy taking care of their children so that they do not have time to take care of themselves and rarely meet biological needs, so this is the thing that triggers the occurrence of Marriage conflict in the second marriage, this affair occurs because fley no longer get dissatisfaction. "He talks about feeling empty, about the family he left behind,about the woman before me and the one before that, the one 22 ho wrecked his head and left him hollow.It comes from shared experience,from knowing how it feels to be broken. "(Hawkin's , 140) 
The quote above is about the feelings of Tom and Megan that happened each in their married life. It turns out that in this second married life that has been equipped with Love and a daughter still causes nothing to Tom. The emptiness that Tom felt was present in his previous married life and feelings in this second married life. The feelings Tom felt coincided with the feelings Megan felt in his married life, so this same experience triggered an affair between the two of them.

"Anna, it was different with you,I swear. That thing with Megan, it was just... Just a bit of fun. That's what it was meant to be. I'II admit it wasn't my finest hour,but I Just needed a release. That's all. It was never going to last. It was never going to interfere with us, with our family. You must understand that. " (Hawkin's , 438)

The quote above is when Tom explains to Anna about Tom's feeling of doing all this. The void that triggers the fun called Tom and Megan affair does not affect Tom's love for Anna, although Tom has an affair, but Tom still loves Anna. This affair is happened because there is no sexual satisfaction so Tom does it with other women, only limited to pleasure without feeling of love. The difference between infidelity in the first marriage and the second marriage is: The first affair raises the sphere of love that decides to get married, but the affair at the second marriage is only limited to pleasure and occurs without a sense of love and responsibility.

\section{The Causes of Marriage Conflict}

Marriage Conflict that occurs in the first marriage and second marriage is caused by two factors, namely external factors and internal factors.

\section{External Factors}

External on the first marriage and the second marriage is the 21 ame, namely the temptress who already fell in love with Tom. External factors at the first marriage is Anna's presence. At that time Tom, who was Rachel's husband, was tempted by Anna's beauty. They have an affair and do a variety of fun together, so this makes Anna fall in love and snatch Tom from Rachel. This makes Rachel feel very down and become an addict Alcohol. Rachel, who is often drunk, makes Anna more confiden 2 o take Tom.

"I think about what's going on down the road and I think about how lucky I am, how I got everything that I wanted. When I look at Tom, I thank God that he found me too, that I was there to rescue him from that woman. She'd have driven him mad in the end, I really think that- she'd have ground him down, she'd have made him into something he's not" ( Hawkin's,166)

The above quote proves that Anna is very confident that she has an affair with Tom. Anna sees that Rachel is so bad that she feels Tom is very lucky to find her. This is something wrong, because it is trying to snatch someone's husband. Anna is a fellow woman she should be able to better understand the feelings of other women, but Anna does not care about it and confidently seize someone's husband so that it destroys other people's marital relationships. This became External factors so that this first marriage ended in Divorce.

External factors in this second marriage are the existence of a teaser named Megan. This is almost the same as the previous marriage. Tom, who already has a wife and Anna, is still teasing other 
women, their baby sitters. Several meetings are held which start from the house to the swan hotel. A variety of fun is done both of them so that Megan falls in love with Tom.

"I told my self that I wouldn't do it again, not after last time, but then I saw him and I wanted him and I thought, why not? I don't see why I should have to restrict my self, losts of people don't." ( Hawkin's , 70 )

The quote above proves that Megan and Tom always agree to not do it again, but Megan who always wants Tom to make him always tease Tom until they finally decide to do various pleasures over and over again. Megan really needs Tom because her married life is very empty and does not get sexual satisfaction with her husband like the satisfaction she always gets fron 11 om.

"I told him I loved him and I felt every muscle in his body tense, as if he knew what was coming and was bracing himself for it. You do, don't you, when someone tells you they love you like that.Iloveyou , I do." ( Hawkin's, 423)

The quote above is Megan's confession to her husband about her feelings for Tom, this affair made her love Tom so she wanted to have Tom more than this, Megan always tried to continue to enjoy the joy of being with Tom and to admit her mistakes to her husband. This makes Megan not stop teasing Tom to continue to do the fun for both of them, until Megan gets pregnant.

\section{Internal Factors}

The internal factor in the first marriage is Tom's selfish nature. The first marriage is established between Tom and
Rachel, they love each other, but after this marriage is 2 years old, they do not also have children. They are in a difficult time that Rachel is very difficult to get pregnant, various efforts and therapies have been done but have not been successful. Tom begins to get bored with this situation and appear emptiness, then he tries to tease 10 her women.

"I feel asleep last night thingking of you, I was dreaming about kissing your mouth, your breasts, the inside of your things. I woke this morning with my head full of you. Desperate to touch you. Don't Expect me to be sane, I can't be, not with you." ( hawkin's 39)

Tom had an affair with Anna and fell in love with an affair. Several meetings ensued so that the affair made Anna pregnant. Tom was very happy with Anna's pregnancy, and then he intended to take responsibility and leave Rachel.

"your marriage broke down. He had an affair. I said." He met another woman and fell in love with her." $n \mathrm{He}$ nodded , waiting for me to go on." It wasn't his fault, though. It was my fault." (Hawkin's 284)

The above quote proves that Tom has ruined his marriage. After leaving Rachel, Tom starts a new life, the second marriage between Tom and Anna.

Internal conflict in the second marriage is selfish and is never satisfied with what it has. A new married life is begun with Tom and Anna. They are blessed with a daughter named Evvie. They love each other and wholeness in a marriage is complemented by the presence of a child, but unlike what is expected, what has been owned is not enough to make Tom to remain loyal to his wife.

"He turs to anna" you were so tired all the time" he saya" you just 
weren't interested. Every thing was about the baby. Isn't that right? It was all about you, wasn't it? All about you ! And just like that, he's on top again,parked up, pulling faces at his daughter, tickling her tummy, making her smile. And megan was so .... Well she was availavble. At first, It was over at her place" and he says " but she was so paranoid about scott finding out . So we started meeting at the Swan. ( Hawkin's ." (436-437)

The quote above proves that Tom still has a selfish nature and is never satisfied so he teases another woman who is their baby sitter named Megan. He had an affair with Megan when his wife was not at home or was exhausted after taking care of their daughter. His wife was so lazy that she didn't have time to take care of herself and fulfill Tom's sexual satisfaction, so she was tempted by Megan's sexiness and then they did things that were out of the ordinary at home and at the hotel. This marriage conflict occurs because he does not get sexual satisfaction from his wife and seeks satisfaction with other women.

\section{THE EFFECT OF MARRIAGE CONFLICT}

The influence of marital conflict that occurs at the first marriage in this novel is divorce. Due to the bad nature of Tom who is selfish and cannot be patient in the difficult circumstances of a marriage, so he had an affair and impregnated a woman named Anna.

The effect of the conflict that occurred in the second marriage between Tom and Anna is death. The conflict at this marriage occurred because Tom's selfish nature could not be lost and Tom was never satisfied. Tom is not grateful for what he has, a wife and children. Tom teases other women when his wife is exhausted and does not have time to take care of himself so that his wife can not provide sexual satisfaction to Tom as before and he had an affair with a beautiful and sexy woman named Megan. This affair was done to satisfy the desire of the two of them to get pregnant and ask for Tom's responsibility, but he accepted this and did not want to take responsibility. Tom began to disappear from Megan because he did not want to be responsile for his actions.

"If he thinks I will just disappear go quietly, he's mistaken. If he doesn't pick up soon, I'm going to stop calling his mobile and call him at home. I'm not just going to be ignore." ( Hawkin's , 197)

The quote above explains that Megan does not accept the treatment of Tom who just disappeared, then he intends to tell all this to Anna. There is a meeting at that tirie between Tom and Megan.

"So we got into the car and drove to corly, to the wood. It was a place we sometimes used to go, if we hadn't got a room. Do it in the car." (Hawkin's , 452)

The quote above proves that there is a meeting between Tom and Megan and there is a fight at that time. Because Tom does not want to be responsible for this action so he is forced to finish Megan during the meeting and hide this to everyone. Megan is gone.

The detectives and the police find out about the disappearance of Megan and after a while Rachel first knows this and tries to tell Anna that Tom is the culprit of Megan's murder. Rachel visits Tom's House.

" In the living room, we sit in a little triangle, Tom on the sofa, the adoring father and dutiful husband, daughter on his lap, wife at his side. And 
the ex-wife opposite,sipping her tea. (Hawkin's , 448)

The quotation above makes it clear that Tom is worried about Rachel at home. Tom is afraid that Rachel would soon tell Anna of all the bad realities of herself and when the meeting took place Rachel tries to call the police but is prevented by Tom and a fight ensued in the violence that Tom does to Rachel. But while everything is going on, Anna secretly tries to call the police, the Rachel tried to break away.

"I watch him come, I watch him, and I don't move until he's almost upon $m e$, and then I swing. I jam the vicious twist of the corkscrew into his neck" ( Hawkin's ." (466)

The quote above proves that there was an act of self-defense because Tom tries to finish off Rachel, but Rachel manages to do it first. Rachel struck Tom's neck using the cork bottle opener and is covered in blood and dies. The impact of Marriage Conflict on this second marriage is an affair that leads to death. Tom becomes a murderer and is killed by his actions.

\section{CONCLUSION}

Marriage conflict occurred during this time is caused by Tom's selfishness and dissatisfaction that hurt the hearts of three women at once. Tom left his exwife, Rachel, because he could not have children makes a woman as his wife then after marriage and undergoes a new marriage, Tom is still teasing another woman namely her baby sitter named Megan to impregnate and kill Megan because she could not accept his fraudulent pregnancy. Tom is a very irresponsible man for his bad deeds. This family confrontation destroys his family, and committed suicide by his actions and caused death.

This research is also intended to reveal Marriage Conflict and the causes of Marriage Conflict, if we cannot have a healthy mind, it will keep us in trouble, this novel must be a motivation for us to refrain from negative thoughts and learn to accept our partner's shortcomings. And give thanks for everything God has given us in our lives.

In this novel the importance of positive thinking is presented through the character of Tom who becomes a selfish and never satisfied husband, thus destroying his marriage and hurting himself. Through this research, the writers trie to reveal to the reader the importance of self-control, don't let selfishness destroy our lives.

\subsection{Suggestion}

Based on the analysis of this novel, the writers wands to give suggestion to the readers. First the anther hopes this thesis can contribute other types of research. Secondly, we must be more patient when we have not achieved what we want, and try to be more restrained on desires that are not appropriate. In order to avoid various life problems, this story usually motivates to be more patient in dealing with various situations. Finally, the writers hopes that the next writers can learn more about other literary works written by Paula Hawkin's.

\section{REFERENCES}

Abrams, Meyer Howard. 1979. The Mirror and The lamp: Romantic theory and Critical Tradition. Oxford University press, USA.

Ally Bacon.1992 “Qualitative Research for Education" on Book An 
Introduction of theory and methods. Boston

Jacob HE, Robert EV .1987." Introduction and writing character analyzing by Roberth and Jacob". On source http://repository.unpas.ac.id Access on july $14^{\text {th }} 3.42 \mathrm{pm}$

Jr Griffith K. 1982. Writing essay about literature. Washington. Harcourt Brace Javanovich publisher Munawar Achmad. 282013." Marriage in general" on journal Sahnya perkawinan menurut hukum positif yang berlaku di Indonesia (P.35). Banjarmasin, Universitas Islam Kalimantan

Paula Hawkins. 2015 "Marriage Conflict" on The Novel The Girl on Train. New York. NouraBooks

Ramulyo Mohd Idris. 1995. On Book

Hukum Perkawinan. Jakarta. Sinar Gravika.

Saver Grade. 2016. " Character The Girl on The Train" on Source http://gradesaver.com/the-girl-on-thetrain/study-guide/character-list.Acces on May 4th 2018.04. $14 \mathrm{Pm}$

Grade Sever. 2016. "Paula Hawkin's bibliography" source http://www. Gradesever.com/author/Paula Hawkin's Subekti. 2015 "Marriage by Paul Scholten". Hukum orang dan keluarga. Bandung 


\section{MARRIAGE CONFLICT IN PAULA HAWKINS'S THE GIRL ON THE TRAIN}

ORIGINALITY REPORT

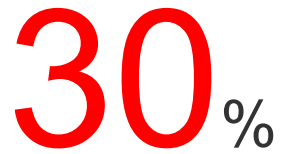

SIMILARITY INDEX

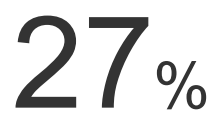

INTERNET SOURCES
$3 \%$

PUBLICATIONS
$24 \%$

STUDENT PAPERS

\section{PRIMARY SOURCES}

1 shakespir.com

Internet Source

2 Submitted to University of Durham

Student Paper

3 en.wikipedia.org

Internet Source

4 Submitted to Yogyakarta Independent School

Student Paper

5 Submitted to Universitas Negeri Manado Student Paper

6 Submitted to Universitas 17 Agustus 1945

Surabaya

Student Paper

7 riset.unisma.ac.id

Internet Source 
9 scornedwifeblog.com

Internet Source

10 Submitted to Columbia 93 School District

Student Paper

11 Submitted to Highland Park Senior High School

Student Paper

12 studylib.net

Internet Source

13 ejournal.stainpamekasan.ac.id

Internet Source

14 ebfinder.com

Internet Source

15 journal.unika.ac.id

Internet Source

16 www.litcharts.com

Internet Source

17 garuda.ristekbrin.go.id

Internet Source

18 Submitted to University of Johannsburg Student Paper

19 www.studymode.com

Internet Source 
21 digilib.uinsby.ac.id

22 www.goodreads.com

23 Xiaomin Li, Hongjian Cao, Jing Lan, Xiaoyan Ju,

Yingxian Zheng, Yi Chen, Nan Zhou, Xiaoyi

Fang. "The association between transition

pattern of marital conflict resolution styles and

marital quality trajectory during the early years

of Chinese marriage", Journal of Social and

Personal Relationships, 2017

Publication

I. Made Suwitra. "The Existence of Same-Sex

Marriage in the Perspective of Human Right and

Legal in Indonesia", Advances in Sciences and

Humanities, 2019

Publication

25

Daniel Hendrawan, Christian Andersen,

Theodora Novia Tjasa. "Legal Protection for

Creditors in Money Loans Agreement Lending

with Constitutional Court's Decision No. 69 /

PUU-XIII / 2015", Journal of Politics and Law,

2019

Publication 
26 WwW.mitrariset.com

27 Submitted to East Tennessee State University

Student Paper

28 WWW.neliti.com

Internet Source

29 louiscorsair.blogspot.com

Internet Source

30 repository.usd.ac.id

Internet Source

"The International Conference on ASEAN 2019", Walter de Gruyter GmbH, 2019 